\title{
10
}

\section{The 'Priceless' Alliance: Paul Dibb and ANZUS}

\section{Benjamin Schreer}

There is hardly a more important strategic question for Australia's defence policy than how close to position itself towards its American ally and how much support to expect from Washington, particularly during times of major changes in the geostrategic environment. As a result, the Australia-New Zealand-United States (ANZUS) alliance has been of singular importance to Paul Dibb's professional life. During the Cold War, he was directly involved in negotiating Australia's intelligence and defence arrangements with the US ally. For instance, as Deputy Secretary of Defence for Strategy and Intelligence, Dibb had a major role in running the policy on the alliance relationship with the United States. He was also closely involved with the alliance's joint intelligence and communications facilities at Pine Gap, Nurrungar and North West Cape. This first-hand experience deeply impressed upon Dibb a fundamental belief in the 'priceless' value of the alliance for Australia's security, derived from privileged access to US intelligence, weapons systems, logistics support and extended deterrence guarantees. ${ }^{1}$

1 Paul Dibb, 'Australia - United States', in Brendan Taylor (ed.), Australia as an Asia-Pacific Regional Power: Friendships in Flux? (London: Routledge, 2007), pp. 36-37. 
Moreover, in his 'second life' as a strategic scholar, Dibb has been a constant contributor to Australia's contemporary debate on ANZUS. His writings on the alliance over more than three decades show an ambivalent strategist who, on the one hand, recognises the huge advantages of being a close US ally, but who also is at times deeply sceptical and wonders if the time has come for Australia to look for alternatives. The analysis also shows that Dibb is a 'classical realist' when it comes to alliance politics: he stresses the importance of values and traditions that tie the two allies together. Moreover, his writings are a testament to the enormous challenges ANZUS has encountered since the collapse of the Soviet Union, its remarkable resilience, and its ability to adapt to those changes. Indeed, after considerable concerns about a potential estrangement between Canberra and Washington, Dibb's answer to the core question of whether any credible alternative exists for Australia under the current geostrategic conditions is a resounding 'no'.

\section{A Unique Alliance}

Nations enter into military alliances either to 'balance' against an external threat (current or future), or to 'bandwagon' with the most powerful actor in the international system. ${ }^{2}$ In Australia's case, 'balancing' against a potentially hostile Asian major power has always been the major rationale behind ANZUS. As Dibb points out, a key role of the alliance for Australia is to sustain the United States' critical role as a 'balancer' in the Asia-Pacific region and to check against hegemonic ambitions of a hostile major power. In his words, 'Asia without the United States would be a much more dangerous place for Australia's strategic interests'. ${ }^{3}$ Moreover, other traditional alliance functions for Australia include the twin pillars of reassurance and deterrence:

The core of the ANZUS alliance has always been the need for protection by a great and powerful friend. The United States has reassured Australia in that regard, from providing extended nuclear deterrence through to an expectation that it would defend Australia in the event of a serious threat by a major power. ${ }^{4}$

2 Stephen Walt, The Origins of Alliances (Cornell University Press, 1987), ch. 2.

3 Paul Dibb, Australia's Alliance with America, Melbourne Asia Policy Papers, Vol. 1, No. 1 (University of Melbourne, Mar. 2003), p. 7.

4 Dibb, Australia's Alliance with America (2003), p. 37. 
For Dibb, however, the 'real' value of ANZUS is 'the access it provides to US intelligence, defence science and advanced weapon systems'. ${ }^{5}$ In combination with US security guarantees, including extended nuclear deterrence, against an existential threat, these factors deliver the 'unique nature of the alliance for Australia' ${ }^{6}$ Indeed, as a member of the UK-US intelligence-sharing agreement of 1946, Australia has enjoyed privileged access to highly classified US intelligence, even if this has not been risk-free. Dibb acknowledges that hosting the joint intelligence, early warning and communications facilities at Pine Gap, Nurrungar and North West Cape during the Cold War most likely made Australia a Soviet nuclear target but that 'this was the price to be paid for the alliance'. ${ }^{7}$ Moreover, through the 'Five Eyes' framework (the intelligence alliance between Australia, Canada, New Zealand, the United Kingdom and the United States), Australia derives significant strategic advantages:

In Australia's case, access to American signals and satellite intelligence and assistance with developing our indigenous intelligence capabilities has been priceless. I mean that in the sense that it is not possible to put a price on how much it would have cost Australia to go it alone and develop such capabilities - it would simply have been beyond Australia's indigenous research and development capabilities. ${ }^{8}$

Dibb is critical of voices in Australia arguing that more money should be invested in the development of a truly independent intelligence capability, stressing that 'frankly, world-class facilities such as Pine Gap cannot be replicated at any price'. ${ }^{9}$ As well, for strategic reasons the intelligence relationship with the US ally remains indispensable:

The very privileged access we have to intelligence of the very highest order is an important force multiplier for Australia, both in peace, to establish an essential transparency and to learn what is and what is not going on, and of course in conflict and war, to give us a leading edge over any potential regional adversary, who simply would not have that access. ${ }^{10}$

\footnotetext{
5 Dibb, Australia's Alliance with America (2003), p. 2.

6 Dibb, Australia's Alliance with America (2003).

7 Dibb, 'Australia - United States' (2007), p. 35.

8 Dibb, 'Australia - United States' (2007), p. 36.

9 Paul Dibb, 'Australia's Defence Relations with the United States', testimony to Joint Standing Committee on Foreign Affairs, Defence and Trade, Defence Subcommittee (2 Apr. 2004), FADT 58. 10 Dibb, 'Australia's Defence Relations with the United States' (2004).
} 
The alliance is also essential for defence science cooperation and Australia's access to advanced US military weapon systems. Examples include access to US combat aircraft such as the F-111, the F-18 and, more recently, the Joint Strike Fighter. It also included advanced torpedoes and weapons systems for the Collins-class submarine; the future submarine is certain to have a US combat system on board. As well, the Navy's new air warfare destroyer is equipped with the US Aegis combat system. These are just the most prominent examples and, from Dibb's perspective, it is almost imperative to keep in mind the value of access to US military equipment since this has 'helped to ensure that Australia has maintained a distinct margin of technological superiority in its own region of primary strategic interest ${ }^{\prime}{ }^{11}$ In fact, as countries in the Asia-Pacific have started to catch up militarily in recent years, he expects Australia's reliance on US defence technology to increase - notwithstanding the fact that Washington remains reluctant to provide certain critical technologies to even its closest allies. ${ }^{12}$

As a consequence, for Dibb, the ANZUS alliance is in many ways 'irreplaceable'13 for Australia, including for its future as a credible defence policy actor in the region and beyond. In this context, he often contrasts Australia with New Zealand's strategic choice:

If Australia did not have access to US intelligence and high technology weapon systems we would have to spend much more on defence. And even then we would not have a credible defence capability - unless, of course, we decided to go down the New Zealand path of having little more than a lightly armed army. ${ }^{14}$

Finally, given his British heritage, one might be tempted to suspect that Dibb represents the tradition of Britain's Lord Palmerston, foreign secretary and two-time prime minister under Queen Victoria, who famously stated that 'Britain had no eternal allies and no perpetual enemies, only interests that were eternal and perpetual'.$^{15}$ In realist logic, US alliances, including with Australia, should therefore have suffered a terminal decline after the end of the Cold War and the

11 Dibb, 'Australia - United States' (2007), p. 36

12 Dibb, 'Australia - United States' (2007), pp. 36-37.

13 Dibb, 'Australia's Defence Relations with the United States' (2004).

14 Dibb, Australia's Alliance with America (2003), p. 3.

15 Quoted in David Brown, Palmerston and the Politics of Policy, 1846-1855 (Manchester University Press, 2002), pp. 82-83. 
demise of a clear, existential threat. ${ }^{16}$ Dibb, however, agrees with Stephen Walt that alliances are 'not merely the product of rational calculations of national interests' ${ }^{17}$ He emphasises that alliances 'involve shared values and belief systems and a shared history of doing things together. They also involve domestic politics. ${ }^{\prime 18}$

Undoubtedly, the ANZUS alliance is an integral part of Australia's strategic culture. ${ }^{19}$ This also helps to explain why the alliance has endured since the collapse of the Soviet Union. Yet, as will be shown later, Dibb has at times been bewildered by certain aspects of US culture and has even considered them as burdensome for the ANZUS alliance. Moreover, recently he has become concerned about the persistence of Australia's bipartisan consensus regarding the centrality of the alliance because of potential changes in public opinion.

One critical conclusion from Dibb's insistence on the fundamental importance of the alliance for Australia is that, despite much debate about his emphasis on Australia's 'defence self-reliance' in the context of the famous Review of Australia's Defence Capabilities (Dibb Review) in 1986, he has always been acutely aware that a degree of 'self-reliance' can only exist within a US alliance context - particularly since the strategic alternatives of 'armed neutrality' and 'non-alignment' have never been attractive for Australian policymakers and the larger public. Instead, Dibb points out that, as the smaller power, the policy of a protective alliance through ANZUS has been and will likely continue to be the preferred option for Australia. ${ }^{20}$

He acknowledges, however, that the lack of real strategic alternatives to the alliance with the United States brings challenges that need to be factored into Australian security and defence policymaking. According to Dibb, 'borrowing someone else's strength has disadvantages as well as advantages' ${ }^{21}$ The disadvantages have been most prevalent during periods when the larger ally is preoccupied with security problems

\footnotetext{
16 See Kenneth N. Waltz, 'The Emerging Structure of International Politics', International Security, Vol. 18, No. 2 (1993), pp. 44-79.

17 Stephen M. Walt, 'Why Alliances Endure or Collapse', Survival, Vol. 39, No. 1 (Spring 1997), p. 156.

18 Dibb, Australia's Alliance with America (2003), p. 4.

19 On strategic culture see Colin S. Gray, 'Strategic Culture as Context: The First Generation of Theory Strikes Back', Review of International Studies, Vol. 25, No. 1 (Jan. 1999), pp. 49-69.

20 Dibb, Australia's Alliance with America (2003), p. 3.

21 Dibb, Australia's Alliance with America (2003).
} 
outside Australia's primary area of strategic interests (i.e. the AsiaPacific) and when the 'unipolar moment'22 in the international system led to hubris on part of the United States. His prescription as to what Australia could and should do to address such situations has, however, been less clear and emblematic of some unresolved challenges for the ANZUS alliance.

\section{ANZUS during the Cold War}

Just like the North Atlantic Treaty Organization (NATO), the origins of ANZUS lie in the early days of the Cold War. As is well known, for Australia, the formation of the alliance with the United States and New Zealand in 1951 was a reassurance against the possibility of a resurgent Japan. Yet, the Korean War demonstrated the fact that the Soviet Union was the real security threat. Moreover, as Dibb points out, 'Moscow's naval deployments into the Indian Ocean and its acquisition of naval bases in Vietnam, as well as its intelligence activities in Canberra, brought the potential threat much closer to home' ${ }^{23}$ In this strategic context, Australia's value as an ally to the United States was considerable since the joint intelligence facilities were critical to 'US confidence in monitoring Soviet strategic nuclear-weapon capabilities and warning of nuclear attack'. From an Australian point of view, US security guarantees were considered essential not just against a possible Soviet aggression. Equally, if not more importantly, particularly during the 1960s the value of ANZUS for Australia was to guard against its bigger neighbour, Indonesia. ${ }^{24}$

During the 1970s and 1980s, however, the Australian strategic community, including Dibb, became concerned with the degree to which Australia could rely on US support in crises, particularly below the threshold of an existential threat. The 'Nixon doctrine' (also known as the 'Guam doctrine') of 1969 made it clear that the United States expected its Asia-Pacific allies to shoulder more of a burden for their own defence. As a consequence, the Strategic Basis of Australian

22 See Charles Krauthammer, 'The Unipolar Moment Revisited', National Interest, Vol. 70 (Winter 2002/03), pp. 5-17.

23 Dibb, 'Australia - United States' (2007), p. 34.

24 Stephan Frühling (ed.), A History of Australian Strategic Policy since 1945 (Canberra: Commonwealth of Australia, 2009), p. 305. 
Defence Policy paper of 1971 stated that 'Australia ... cannot assume that the United States will necessarily provide assistance with the speed, of the type, and on the scale that we might think necessary' ${ }^{25}$ This assumption paved the way for Australia's thinking about 'defence self-reliance within the alliance' and Dibb played a major role in its conceptualisation.

Towards the end of the 1970 and early 1980s it became clear to Dibb that the threat perceptions of the two allies did not always align. In his words, during that period the United States:

became ever more obsessed with the growing military capabilities of the Soviet Union. As late as 1984, the Central Intelligence Agency (CIA) was predicting that the Soviet Union would soon outstrip America in terms of its military might [emphasis added]. ${ }^{26}$

The CIA's assessment was contrary to Dibb's own conclusion, articulated in the late 1980s, arguing that the Soviet Union was an 'incomplete superpower', unable to overcome the strategic advantages of the United States. ${ }^{27} \mathrm{He}$ was also puzzled as to why 'everything that the Soviet Union did in the Asia-Pacific region, including its trade and aid activities, was treated with potential hostile intent by the United States' ${ }^{28}$

Moreover, during the 1980s Dibb also experienced the US ally as a hard-headed partner to deal with. For instance, he describes the Labor Government's decision to acquire 'full knowledge and concurrence' about US operations in the joint intelligence facilities, leading to one of the 'most difficult negotiations that Australia had with the United States ... [which were] ... [l]ong, drawn out and sometimes tense'. ${ }^{29}$ Finally, Dibb witnessed how New Zealand became, in his words, the 'naughty boys' ${ }^{30}$ in the 1980s when, in response to the ally's antinuclear stance, Washington excluded Wellington from access to the close intelligence-sharing arrangements.

25 Frühling, A History of Australian Strategic Policy (2009), p. 401.

26 Paul Dibb, 'America and the Asia-Pacific Region', in Robert Ayson \& Desmond Ball (eds),

Strategy and Security in the Asia-Pacific (Sydney: Allen \& Unwin, 2006), p. 178.

27 Paul Dibb, The Soviet Union: The Incomplete Superpower, 2nd edn (London: International Institute for Strategic Studies and Macmillan, 1988).

28 Dibb, 'America and the Asia-Pacific region' (2006), p. 179.

29 Dibb, 'Australia - United States' (2007), p. 35.

30 Dibb, 'Australia's Defence Relations with the United States' (2004). 
It is reasonable to assume that those experiences contributed to the 1986 Dibb Review, the first coherent document outlining the rationale and requirements for a self-reliant Australian defence policy. While Dibb recognised the importance of the alliance in terms of deterring against 'higher level threats', access to intelligence and defence technology, as well as military logistics, the review also reflected his reservations against relying too much on the United States:

Our close relationship with the United States is significant for our security and the development of our defence capability, but for over a decade we have recognised that the United States is a global power with a variety of interests, none of them centred on Australia. There are potential situations where we would not expect the United States to commit combat forces on our behalf and where we need a demonstrably independent combat capability. ${ }^{31}$

Moreover, his review pointed out that the ANZUS Treaty did not entail an automatic obligation for the United States to defend Australia. Thus, it was 'realistic to assume that the parties will continue to approach each situation in accordance with their respective national interests' ${ }^{32}$

Dibb's main conclusion in the report, however, was that possible alliance contingencies should not be the primary determinant for ADF force planning and equipment decisions. ${ }^{33}$ Whilst the review stressed that Australia could not and should not aim for a fully independent defence policy, and that the ANZUS alliance remained a fundamental pillar of its strategic posture, Dibb's reasoning also demonstrates that, even before the Soviet Union collapsed in 1989, there was a cooling of the ANZUS alliance brought about by a relative divergence of strategic interests and the fact that, unlike NATO, the alliance was not highly institutionalised. That is, ANZUS does not have an integrated military command structure or a standing political committee akin to NATO's North Atlantic Council, which provides maximum flexibility but which can make effective consultations during periods of strategic drift more difficult. This drift became even more apparent in the immediate post-Cold War era.

31 Paul Dibb, Review of Australia's Defence Capabilities, report to the Minister for Defence

(Canberra: Australian Government Publishing Service, 1986), p. 46.

32 Dibb, Review of Australia's Defence Capabilities (1986).

33 Dibb, Review of Australia's Defence Capabilities (1986), p. 47. 


\section{In Search of a New Consensus: ANZUS in the 1990s}

Following the rather sudden collapse of the Soviet Union, the alliance was left without an adversary. Australian strategic policymakers were particularly concerned with what Dibb later called a:

rather surreal American attitude to international security and alliance relationship. We were not on the radar screen in the 1990s in Washington in the same way as we were undoubtedly in Cold War. There was a sense of drift and of, if not irrelevance, a lack of importance. ${ }^{34}$

In a 1993 address to the National Press Club in Canberra, Dibb impressed upon his audience that:

naturally, with the end of the Cold War and the collapse of the Soviet Union, Australia has become rather less strategically important for the US. Australia is still seen as a valued ally, but Australia's strategic value to the US is necessarily affected by the lack of important US strategic objectives in our immediate region in the post-Cold War era. ${ }^{35}$

As a consequence, he called for the development of an 'order-based alliance $^{36}$ as opposed to the old threat-based alliance model. Echoing then Labor Foreign Minister Gareth Evans's approach to community building with Asian countries, Dibb saw the gradual emergence of a 'community of strategic interests' between Australia and the ASEAN countries, supported by the US administration of President Bill Clinton. Indeed, according to Evans, the new sense of purpose for the ANZUS alliance was that the 'United States should be encouraged to participate in a multilateral approach to the development of a new community of strategic interests in the 1990s. Such a community could be based on America's traditional regional allies and the ASEAN group.' ${ }^{37}$

\footnotetext{
34 Dibb, 'Australia's Defence Relations with the United States' (2004).

35 Paul Dibb, The Future of Australia's Defence Relationship with the United States, Working Paper No. 276 (Canberra: Strategic and Defence Studies Centre, 1993), p. 1.

36 Dibb, The Future of Australia's Defence Relationship with the United States (1993), p. 5. Italics in the original text.

37 Dibb, The Future of Australia's Defence Relationship with the United States (1993), p. 7.
} 
By today's standards, this proposition reads as being rather ambitious. Yet, Dibb ended his talk with an even starker prediction:

as we develop a more self-reliant defence policy and a community of strategic interests with our ASEAN friends, the US will not be so central to our defence policy. All this suggests to me that a much more equal alliance partnership will develop between Australia and the US in the coming decade [emphasis added]. ${ }^{38}$

In hindsight, his prediction about a declining importance of the United States for Australia's defence policy did not materialise. Quite the opposite. The same is true for his envisaged 'community of strategic interest' with the Association of Southeast Asian Nations (ASEAN). Dibb's reasoning reflected, however, some common strands of thinking in international security circles at the time. One was uncertainty about the role the United States was willing to play in international affairs in general, and the viability of its alliance system more specifically. The other was cautious optimism about the opportunity to build new multilateral security arrangements, including in the Asia-Pacific. As such, Dibb's scepticism about the future of ANZUS and his pledge to look for complementary security arrangements were not unusual. But it also shows his ambivalent feeling towards relying too heavily on the larger ally.

Nevertheless, during the second half of the 1990s Dibb's assessment of ANZUS became less gloomy. Indeed, given the uncertainty surrounding the future security order in the Asia-Pacific, it was better, in his view, to maintain a close relationship with the Americans. Writing in 1997, Dibb warned about the challenges of a rising China for the regional security order: 'There is no more important question in Asia than the future role of China. Almost nothing is so destabilising as the arrival of a new economic and military power on the international scene. ${ }^{\prime 39}$

He also stressed that while it was 'far from certain that the American alliance system will decay ... America's alliance partners perceive that they will need to do more militarily for themselves' ${ }^{40}$ This referred to the old question about 'burden-sharing' within the alliance. For

38 Dibb, The Future of Australia's Defence Relationship with the United States (1993), p. 10.

39 Paul Dibb, 'The Emerging Strategic Architecture in the Asia-Pacific Region', in Denny Roy (ed.), The New Security Agenda in the Asia-Pacific Region (London: Macmillan, 1997), p. 110.

40 Dibb, 'The Emerging Strategic Architecture in the Asia-Pacific Region' (1997), p. 112. 
Dibb, the ANZUS alliance was going to be one element of the emerging Asian 'security architecture', encompassing traditional alliances and multilateral security fora such as the ASEAN Regional Forum (ARF). Yet, while he still advocated the evolution of an Asian 'strategic community', he appeared less certain about its chances for success. One key reason in this respect was doubt over continued ASEAN cohesion. In what has become of great interest in current Asian strategic debate, Dibb pointed out in 1997 that China's growing power and influence had serious potential to split ASEAN. ${ }^{41}$ Worse, some ASEAN countries might even 'bandwagon' with China. In such an environment, the 'case for strengthening Australia's own defence spending and seeking greater alliance commitments from the United States ... would become more compelling'. ${ }^{42}$ Australia, therefore, needed 'to keep its traditional alliances in good repair'.$^{43}$ After all, for Dibb, the ANZUS alliance was critical to put some elements of restraint on China's potential quest for regional hegemony, particularly in South-East Asia, Australia's immediate strategic neighbourhood. ${ }^{44}$ Despite its weaknesses, the US alliance remained the ultimate reassurance for the time when the period of 'strategic pause' in the Asia-Pacific might come to an end.

\section{Power and Hubris: ANZUS after 9/11}

When President George W. Bush took office in 2001, Dibb was expecting that the new US administration would focus more on Asia and less on Europe ${ }^{45}$ Yet, his hopes quickly faded after the terror attacks on the United States on 11 September 2001. Subsequently, the United States launched its 'global war on terror' and expected its allies, including Australia, to support it in its wars in Afghanistan and Iraq. After 9/11, and for the first time in history, Australia invoked the ANZUS treaty to support its US ally. More controversially, the Coalition Government under John Howard also participated in the US-led campaign against Iraq in 2003.

41 Paul Dibb, Alliances, Alignments and the Global Order: The Outlook for the Asia-Pacific Region in the Next Quarter-century, Working Paper No. 317 (Canberra: Strategic and Defence Studies Centre, Dec. 1997), p. 11.

42 Dibb, Alliances, Alignments and the Global Order (1997), p. 12.

43 Dibb, Alliances, Alignments and the Global Order (1997).

44 Dibb, Alliances, Alignments and the Global Order (1997), pp. 6-7.

45 See Paul Dibb, 'New Defence Alignments', interview, BBC AM, 31 Jul. 2001. 
In Dibb's view, 9/11 had a number of effects on the ANZUS alliance. First, the relationship became 'extremely close again - arguably even closer than in the Cold War'. ${ }^{46}$ Second, Australia's larger ally enjoyed a unique power position in the international system and Dibb, in 2003, argued that the United States was 'unlikely to face a peer competitor, or even a combination of hostile powers, in the foreseeable future' ${ }^{47}$ Thirdly, and most importantly, Washington appeared to use this power in a different way. Dibb shared the view that the United States was 'no longer a status quo power, as it was in the Cold War. It has become very demanding of allies, including us, and ... it is now inclined to be more interventionist, more unilateralist and more inclined to use force. ${ }^{\prime 8}$ It became quickly apparent that the Bush administration had a much more instrumental view of alliances, which led to an international debate about whether this might even be the end of traditional alliances. ${ }^{49}$

While Dibb did not go so far, he saw America's behaviour as a 'hyper power' as problematic for Australia. He was particularly critical of Washington's decision to intervene militarily in Iraq in 2003 and the Howard Government's willingness to support Operation Iraqi Freedom. On the eve of the operation, he warned that the alliance was now 'in more danger, and certainly under more pressure than at any time since the Vietnam War' ${ }^{.50}$ Dibb was particularly worried that the bipartisan consensus on the importance of ANZUS would erode as a result of a war started without a United Nations Security Council resolution. ${ }^{51}$ Moreover, he feared negative implications from Australia's unquestioning support for the US ally for Canberra's regional standing:

Australia's very closeness to the US now threatens to complicate, if not challenge, some of our key relations in Asia. The initial outpouring of sympathy towards the US after September 11 has been replaced in some (but by no means all) parts of our region by a growing sense of unease that America is a unilateral power dismissive of the norms of international behaviour, except on its terms. The perception in

49 See Kurt M. Campbell, 'The End of Alliances? Not So Fast', Washington Quarterly, Vol. 27,

51 Paul Dibb, 'Bipartisan Ties with the US are Critical', Australian, 15 Jun. 2004. 
some parts of the region that Australia is America's deputy sheriff has also stuck ... at least in some respects the alliance now threatens to divide us from some parts of our own region. ${ }^{52}$

As a consequence, he saw the alliance at 'a crucial point in Australia'53 and argued that 'while still a close and loyal ally of the US, it is vital that Australia is seen to have an independent capacity when it comes to resolving security challenges in our own region' ${ }^{54}$ Critically for Dibb, America's (and Australia's) 'adventures' in the Middle East were distractions from the bigger strategic questions that were playing out closer to home. The terrorist threat for Australia, for instance, was more likely to come from neighbouring Indonesia. But, most importantly, by taking its eyes off the ball in the Asia-Pacific region, Dibb feared that the United States allowed China to fill some of the strategic vacuum created. Writing in 2006, he argued that America's 'singular obsession' with terrorism led to the risk that the 'second Bush administration will overlook or pay insufficient attention to more traditional security problems in Asia'. ${ }^{55}$

\section{ANZUS and the Rise of China}

As mentioned before, China's rise was potentially the biggest of those emerging traditional security problems. In 2008, Dibb spelled out the coming strategic challenge posed by Beijing's economic and military growth for the regional order:

I expect that by 2020 China will have a much more survivable strategic nuclear force (both land-based and sea-based intercontinental ballistic missiles) and - unless Japan spends a lot more on defence - the most potent naval and air forces of any Asian great power. It may well have an operational aircraft carrier capability in this timeframe, as well as advanced antisatellite capabilities and some form of ballistic missile defence. The strong growth of China's political and military power will enable it to dominate its maritime approaches and make survival much more hazardous for US naval forces, especially in the Taiwan Strait. We can expect to see China have more influence even

\footnotetext{
52 Paul Dibb, 'The Downside of being Too Close to the US', Age, 4 Apr. 2003.

53 Dibb, Australia's Alliance with America (2003), p. 9.

54 Dibb, Australia's Alliance with America (2003), p. 10.

55 Dibb, 'America and the Asia-Pacific region' (2006), p. 188.
} 
than today in Southeast Asia, which it sees as its natural sphere of influence, and it may come to have more influence in South Korea than the United States. ${ }^{56}$

Most of these predictions ring true today. Interestingly, Dibb has more recently argued that China's military is largely a paper tiger, unable to pose a significant military operational challenge to the United States. ${ }^{57}$

Regardless, by 2010, China's growing power, the strategic quagmires in Iraq and Afghanistan, and the global financial crisis increased the realisation that America's 'unipolar moment' (if there ever was one) was quickly coming to an end. Dibb stated in 2009 that in an 'increasingly multi-polar Asia region and some uncertainty surrounding the issue of US strategic primacy', Australia had to become 'more self-reliant in its defence' ${ }^{58} \mathrm{He}$ was therefore critical of Australia's 2009 Defence White Paper, which called for greater preparedness of the Australian military to fight alongside its US ally in distant theatres. On the other hand, however, Dibb conceded that in the area of military technology, for instance, Australia's dependence on the United States would only increase in the years ahead. ${ }^{59}$

In any event, the rise of China provided ANZUS with the new rationale that Dibb called for in the 1990s. That is, China's emergence as a serious challenger to the Asia-Pacific regional security order and the position of the United States as a guarantor of peace and stability has given the alliance a new sense of urgency. Importantly for Dibb, this situation has required the United States to refocus on Australia's own region. As a consequence, he has been a strong supporter for the administration of President Barak Obama and its 'strategic rebalance' of Asia, first announced in Canberra in November 2011. He defended the decision of the government of Prime Minister Julia Gillard to allow for the rotation of US Marines through Australia's bases in the north of the continent as an important step to enhance deterrence in times of strategic change. In this context, he argued that the terminal decline

\footnotetext{
56 Paul Dibb, The Future Balance of Power in East Asia: What are the Geopolitical Risks?, Working Paper No. 406 (Canberra: Strategic and Defence Studies Centre), p. 3.

57 See Paul Dibb \& John Lee, 'Why China Will Not Become the Dominant Power in Asia', Security Challenges, Vol. 10, No. 3 (2014), pp. 1-21; Paul Dibb, 'Why the PLA is a Paper Tiger', ASPI: The Strategist, 15 Oct. 2015.

58 Paul Dibb, 'Is the US Alliance of Declining Importance to Australia?', Security Challenges, Vol. 5, No. 2 (Winter 2009), p. 38.

59 Dibb, 'Is the US Alliance of Declining Importance to Australia?' (2009), p. 39.
} 
of the United States as a major power in Asia was far from given and that Australia could not provide China with a veto over closer alliance relations:

We should not be in the business of accommodating China on key issues of our own security just because of some narrow mercantile views of the relationship. Neither should we eschew opportunities to enhance our longstanding alliance with the US because of premature notions of that great nation's decline. ${ }^{60}$

Since 2011, Dibb has consistently pointed out that the ANZUS alliance is crucial for upholding a regional order which benefits Australia (and the rest of the region) economically and security-wise. He has also been blunt in his criticism of Chinese strategic behaviour:

The fact is that the Asia-Pacific region without the US would be a much more dangerous place for us. It is not in our interest to see a retraction of US military might. Nor do we want to see China develop the military capability to challenge decisively US military power in the western Pacific. China is becoming more assertive of late and shows little interest in maintaining order in a part of the world where arms races are occurring and where there are not the arms control and military confidence-building measures necessary for reassurance. It is the US and its allies that are largely responsible for supporting order and stability, which is so crucial to the economic wellbeing of the region - including China. It is China, however, that is now challenging multiple territorial claims in the South China Sea and elsewhere. ${ }^{61}$

China's rise, therefore, has also to some extent lessened the need for a more self-reliant Australian defence posture, which would be of limited value against a major power equipped with nuclear weapons. Instead, Dibb is now comfortable with ever deeper integration between US and Australian forces. Moreover, in the current dispute over China's creation of 'artificial features' in the South China Sea, he has been firm in his call for Australia to join the United States in challenging Beijing's unilateral claims by sending warships and military aircraft to

60 Paul Dibb, 'US Build-up no Threat to Peace', Australian, 15 Nov. 2011.

61 Paul Dibb, 'Modest US Military Presence is in our Interest', Australian, 4 May 2012. 
these waters, even if that would draw a negative Chinese response. ${ }^{62}$ In his logic, the alliance has regained the critical importance it had during the height of the Cold War.

\section{Conclusion}

As Australia faces a more uncertain Asia-Pacific strategic environment, the national debate about the relative costs and benefits of remaining a close US ally is likely to intensify. After all, the decision whether and how to support the United States in regional theatres will be much more consequential than deploying Australian soldiers to the Middle East. Yet, in Dibb's logic the answer is clear: the biggest threat for the alliance is distraction by the United States and the absence of a clear challenger. As long as the United States retains a strong strategic footprint in the region, Canberra is well-advised to remain close to Washington in these times of strategic change. Dibb does not buy the argument that the price for standing up to China might well be too high.

As Rob Ayson points out in his contribution to this volume, for Dibb, geography is a key factor determining Australia's security. ${ }^{63}$ In some sense then, the utility of the US alliance for Australia is tied to the geographic proximity of a potentially serious military challenge. In other words, in times when the US ally is preoccupied with secondary security challenges outside Australia's own region, the pressure on the alliance to maintain cohesion and purpose increases, and so does the need to develop a more independent defence posture. The moment when the US ally concentrates on keeping a potentially hostile major power in Australia's key area of strategic interest in check, however, the higher becomes the incentive for Australia to stay close to its ally and to eschew costly alternatives. Expect Dibb to be a strong supporter of the US alliance as China seeks to fundamentally change the Asia-Pacific security order.

62 Paul Dibb, 'Chinese Expansion Calls for Firm Challenge', Business Spectator, 5 Jun. 2015.

63 Rob Ayson, 'The Importance of Geography', ch. 6, this volume. 
This text is taken from Geography, Power, Strategy and Defence Policy: Essays in Honour of Paul Dibb, edited by Desmond Ball and Sheryn Lee, published 2016 by ANU Press, The Australian National University,

Canberra, Australia. 